\title{
クロロフィルおよびクロロフィル誘導体による Lーアスコルビン酸の光増感分解に関する研究
}

\author{
Photosensitizing Decomposition of L-Ascorbic Acid by Chlorophylls \\ and Chlorophyll Derivatives
}

（昭 和 45 年 4 月 7 日 受 理）

\begin{tabular}{|c|c|}
\hline $\begin{array}{l}\text { 守 康 則* } \\
\text { (Yasunori Mori) }\end{array}$ & $\begin{array}{l}\text { 上田 マ リ } \text { 子 }^{*} \\
\text { (Mariko Ueda) }\end{array}$ \\
\hline $\begin{array}{l}\text { 三宅 璋 子* } \\
\text { (Akiko Miyake) }\end{array}$ & $\begin{array}{l}\text { 三 輪 和 子* } \\
\text { (Kazuko Miwa) }\end{array}$ \\
\hline
\end{tabular}

The effects of chlorophyll a, pheophytin and chlorophyll metal derivatives on the photochemical decomposition of $\mathrm{L}$-ascorbic $\operatorname{acid}\left(\mathrm{AAH}_{2}\right)$ and also the photochemical decomposition of chlorophyll- $\mathrm{AAH}_{2}$ system with co-existence of potassium ferri-cyanide, $p$-quinone and $\beta$-carotene as fluorescence quenching agents was studied.

1. The photochemical decomposition of $\mathrm{AAH}_{2}$ was greatly accelerated by the existence of chloro phyll a and pheophytin, and the photodecomposition rate was also promoted with $\mathrm{Cu}$-chlorophyllin $\mathrm{Na}$ and $\mathrm{Fe}$-chlorophyllin- $\mathrm{Na}$, especially, by the former. $\mathrm{Cu}$-chlorophyllin- $\mathrm{Na}$ itself oxidized $\mathrm{AAH}_{2}$.

2. The photodecomposition of chlorophyll- $\mathrm{AAH}_{2}$ system was protected with the co-existence of $\mathrm{K}_{3} \mathrm{Fe}(\mathrm{CN})_{6}, p$-quinone and $\beta$-carotene. However, the effect of $p$-quinone seems to be accelerated the photodecomposition of chlorophyll- $\mathrm{AAH}_{2}$ system in higher concentration.

3. Chloropyll and pheophytin have comparatively strong fluorescence intensity, whereas Cu-chlorophyllin $\cdot \mathrm{Na}$ and $\mathrm{Fe}$-chlorophyllin $\cdot \mathrm{Na}$ have week fluorescence intensity. The mutuality relationship was found between the fluorescence intensity of the reaction system and the photochemical decomposition of $\mathrm{AAH}_{2}$.

\section{緒言}

著者は先に Lーアスコルビン酸の光分解について，と くにリボフラビンおよびェオシン,フルオレセインなど のエオシン系の光增感色棠の共存下に Lーアスコルビ ン酸の光分解がいちじるしく促進されることを報告し た1)。

光化学色素であるクロロフィルす光を吸収して励起さ れケイ光を発し、リボフラビン, エオシン系色素と同様 に Lーアスコルビン酸の光分解促進作用をるつことが推 考される。クロロフィルによる Lーアスコルビン酸の光 增感分解反応の 解明は, 有色々菜に拈ける眝蔵加工時 のレーアスコルビン酸の光化学的分解機構を明らかにす る上からも意義あるすのと考える。なお,クロロフィルに よるレーアスコルビン酸の光增感分解反応においては, とくに反応系のケイ光強度と Lーアスコルビン酸の光增 感分解との関係を重要視し, 検討を加えた。すなわち有 色そ菜にクロロフィルと共存し, 比較的豊富な分布をみ

* 広島大学教育学部
るカロチノイド，キノン類のクロロフィルケイ光消光剤 としての機能に注目( 2)3)，クロロフィルによるLーアス コルビン酸の光增感分解反応に打ける $\beta$-カロチン, $0-$ キノンの代りとして $p$-キノンをえらび，これらの影響 をも併せ検討した。

\section{実験材料および実験方法}

1. カラムクロマトグラフィーによるクロロフィルa の調製：前報)と同様にして調製した。

2. フェオフィチンの調製と定量：前報 ${ }^{4)}$ と同様に Pennington 55) の方法に準拠して調製し, A. O. A. C. ${ }^{6)}$ の式に従って定量した。

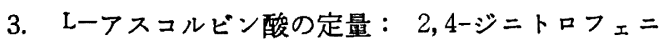
ルヒドラジン溶液を用いる Roe法》の変法に準拠して定 量を行なった。Lーアスコルビン酸の光分解度は $530 \mathrm{~m} \mu$ におけるレーフスコルビン酸の吸光度(オサゾン)より算 出した。

4. 照射方法: ᄂーアスコルビン酸とクロロフィルaの Meorl混夜 $10 \mathrm{ml}$ を内径 $(1.5 \times 16.5 \mathrm{~cm})$ の硬質無色試 
験管に入れ, 小型定温水槽に保持し, 光源として東芝製 $100 \mathrm{~V}, 200 \mathrm{~W}$ タングステンフィラメントランプを用い $30^{\circ} \mathrm{C}$ にて試験管表面までの距離的 $10 \mathrm{~cm}$ にて直上より 照射処理を行なった。なお対照として試験管をアルミニ ウム箔にて包み, 定温水槽に保持し, これを暗所処理

（無照射）のbのとした。

\section{実験結果および考察}

1. Lーアスコルピン酸の光分解に対するクロロフィ

\section{ルの影響}

$\pi$ 電子系を的色素は一般に光を吸収し, 吸収された 光エネルギーの一部はケイ光またはリン光として再び放 出される。クロロフィルはケイ光を有し, 光増感色素とし て注目され，とくにクロロフィルの光の吸収は不飽和結 合をるつポルフィリン構造が関係をるつとされている。 これらの見地よりクロロフィルa $5 \mathrm{ml} 20 \mathrm{mg} \%-\mathrm{AAH}_{2}$ $\mathrm{MeOH}$ 溶液 (pH 5.0) $5 \mathrm{mlk}$ 加え, クロロフィルa の反 応液中の濃度 $2.5 \mathrm{mg} \%, 5 \mathrm{mg} \%$ にて光照射処理を行な い, $\mathrm{AAH}_{2}$ の光分解に対するクロロフィルの影響をしら べた。結果は第 1 図に示されるごとく $\mathrm{AAH}_{2}$ の光分解は クロロフィルによっていちじるしく促進される。これは クロロフィルが光照射により光エネルギーを吸収して励 起され, この励起クロロフィル分子の光增感反応により $\mathrm{AAH}_{2}$ の光分解が促進されるすのと考える。

Fig. 1. Effect of chlorophyll a upon the photochemical decomposition of L-ascorbic acid

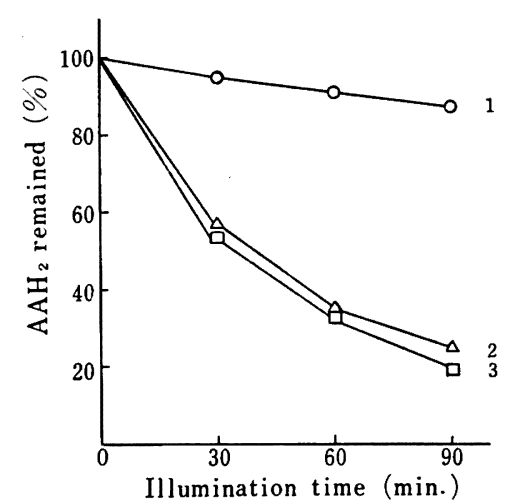

1: $\mathrm{AAH}_{2} 10 \mathrm{mg} / 100 \mathrm{~m} l \mathrm{MeOH}, \mathrm{pH} 5.0$

2: $\mathrm{AAH}_{2} 10 \mathrm{mg} / 100 \mathrm{ml} \mathrm{MeOH}$, chl. a $2.5 \mathrm{mg} /$ $100 \mathrm{ml} \mathrm{MeOH}$

3: $\mathrm{AAH}_{2} 10 \mathrm{mg} / 100 \mathrm{ml} \mathrm{MeOH}$, chl. a $5.0 \mathrm{mg} /$ $100 \mathrm{~m} l \mathrm{MeOH}$

2. ᄂーアスコルビン酸の光分解に対するクロロフィ ル誘導体の影響

(1) フェオフィチンの効果：クロロフィルの Mgの水 (380)
Fig. 2-1. Effect of pheophytin a upon the photochemical decomposition of L-ascorbic acid

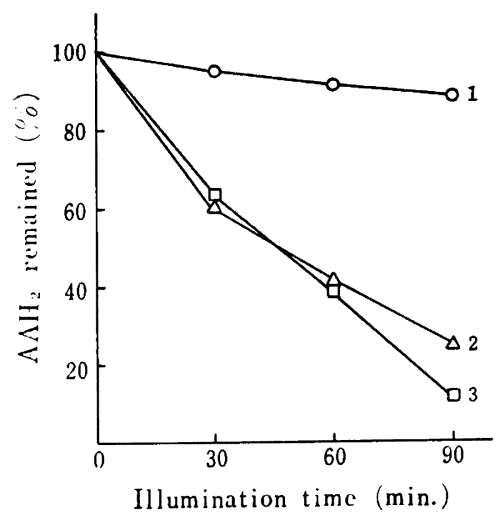

1: $\mathrm{AAH}_{2} 10 \mathrm{mg} / 100 \mathrm{ml} \mathrm{MeOH}, \mathrm{pH} 5.0$

2: $\mathrm{AAH}_{2} 10 \mathrm{mg} / 100 \mathrm{ml} \mathrm{MeOH}$, pheophytin $2.5 \mathrm{mg} / 100 \mathrm{ml} \mathrm{MeOH}$

3: $\mathrm{AAH}_{2} 10 \mathrm{mg} / 100 \mathrm{ml} \mathrm{MeOH}$, pheophytin $5.0 \mathrm{mg} / 100 \mathrm{ml} \mathrm{MeOH}$

素置換体であるフェオフィチンもポルフィリン構造をる ち, ケイ光を有し，クロロフィルと同じく光增感色素と して $\mathrm{AAH}_{2}$ を光增感分解せしめることが考えられるので フェオフィチン共存下に拈ける $\mathrm{AAH}_{2}$ の光分解性を検討 した。結果は第 2-1 図に示されるごとくフェオフィチン は $\mathrm{AAH}_{2}$ の光分解るいちじるしく促進する。

(2) 銅クロロフィリンナトリウム扰よび鉄クロロフィ リンナトリウムの効果：クロロフィリンの金属誘導体で ある銅クロロフィリンナトリウム扰よび鉄クロロフィリ ンナトリウムはいずれも法定天然食用着色料として広く 使用されて扣り，これらもケイ光を有しクロロフィルと 同じく $\mathrm{AAH}_{2}$ を光増感分解せしめることが考えられるの で, 銅クロロフィリンナトリウム（片山化学製品特級） および鉄クロロフィリンナトリウム(片山化学製品特級) 共存下における $\mathrm{AAH}_{2}$ の光分解性を検討した。結果は第 2-2 図に示されるごとく銅クロロフィリンナトリウム, 鉄クロロフィリンナトリウムにより $\mathrm{AAH}_{2}$ の光分解は促 進される。なむうクロフィリン金属塩はいずれる水溶液 を用い, $\mathrm{AAH}_{2} \mathrm{MeOH}$ 溶液について光照射処理を行な った。さらに金属誘道体の金属イオンによる $\mathrm{AAH}_{2}$ の分 解が考えられるので対照として暗所処理のものを併せ行 なった。暗所に拈ける鉄クロロフィリンナトゥムの $\mathrm{AA}$ $\mathrm{H}_{2}$ の分解に対する影響は比較的少ないか，銅クロロフ ィリンナトリウムによる $\mathrm{AAH}_{2}$ の酸化分解はいちじるし i.

3. クロロフィルーアスコルビン酸系の光分解に対す 
Fig. 2-2. Effect of Fe-chlorophyllin-Na and $\mathrm{Cu}$-chlorophyllin- $\mathrm{Na}$ upon the photochemical decomposition of L-ascorbic acid

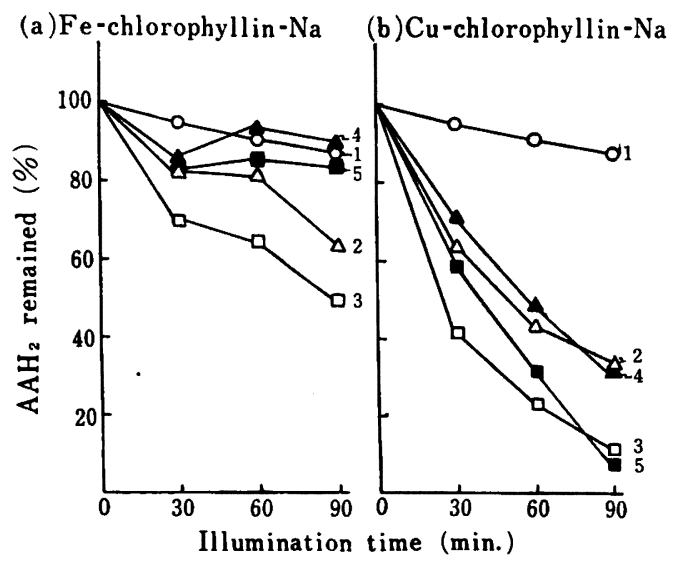

$\mathrm{AAH}_{2}: 10 \mathrm{mg} / 100 \mathrm{ml} \mathrm{MeOH}, \mathrm{pH} 5.0$

1: Control (without Fe-chlorophyllin-Na, $\mathrm{Cu}$-chlorophyllin-Na) under light

2: Fe-chlorophyllin- $\mathrm{Na}, \mathrm{Cu} \cdot$ chlorophyllin- $\mathrm{Na}$ $2.5 \mathrm{mg} / 100 \mathrm{ml}$ added under light

3: Fe-chlorophyllin- $\mathrm{Na}, \mathrm{Cu} \cdot$ chlorophyllin- $\mathrm{Na}$ $5.0 \mathrm{mg} / 100 \mathrm{ml}$ added under light

4: Fe-chlorophyllin- $\mathrm{Na}, \mathrm{Cu}$-chlorophyllin- $\mathrm{Na}$ $2.5 \mathrm{mg} / 100 \mathrm{ml}$ added in dark

5: Fe-chlorophyllin- $\mathrm{Na}, \mathrm{Cu}$-chlorophyllin- $\mathrm{Na}$ $5.0 \mathrm{mg} / 100 \mathrm{ml}$ added in dark

るフェリシアン化カリウム， $p$-キノンおよび $\beta$-カロチ ンの影響

緑葉にはクロロフィルに伴ってカロチノイドが豊富に

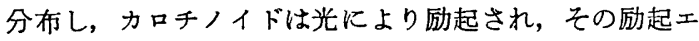
ネルギーのクロロフィルへの移動性が指摘されておりる) 10)，また $\beta$-カロチンはクロロフィルの三重項状態(triplet state)のケイ光消光剤（電子受容体）としての機能 をすつことが報告されている2)。また植物体にはク口ロ ゲン酸, カテキン類, ロイコアントシアン類, タンニン など多、いポリフェノール化合物が分布し，これらは酸 化酵素により ○ーキノンを生じ，これが酸化重合して褐 变物質を生ずることが知られて扣り，とくに は反応性に富み, 当然クロロフィルケイ光消光剤として の機能をすつことも推考される2)。Murataら は11)はウ レン草の光合成における光化学反応の実験においてフェ リシアン化カリウムが葉粶体のクロロフィルのケイ光消 光剤として働くことを報告している。これらの植物体に おける生化学的反応の見地より，とくにカロチノイド， キノン, フェリシアン化カリウムのクロロフィルケイ光 消光剤としての機能を重要視して $\beta$-カロチン， 0 ーキノン の代りとしてp-キノン，さらにフェリシアン化カリウム をえらび，クロロフィル- $\mathrm{AAH}_{2}$ 系の光分解に対するそれ ぞれの举動を検討した。

フェリシアン化カリウムの効果についてみると第 3-1 図に示されるごとくフェリシアン化カリウムによるクロ ロフィル $-\mathrm{AAH}_{2}$ 系の光分解反応に 対する抑制力がみと められるが, これはフェリシアン化カリウムの添加にと もならクロロフィルのケイ光強度の消光(第 4-4 図参照) と守らが前報》に報告したごとくフェリシアン化カリウ ムの鉄イオンによるクロロフィルの分解退色に原因する あのと推考する。なお $10^{-4} \mathrm{M}$ の高濃度においてはフェ リシアン化カリウム自体による $\mathrm{AAH}_{2}$ の接触酸化の增大 がみられる。

Fig. 3-1. Effect of potassium ferricyanate upon the photochemical decomposition of chlorophyll-L-ascorbic acid system

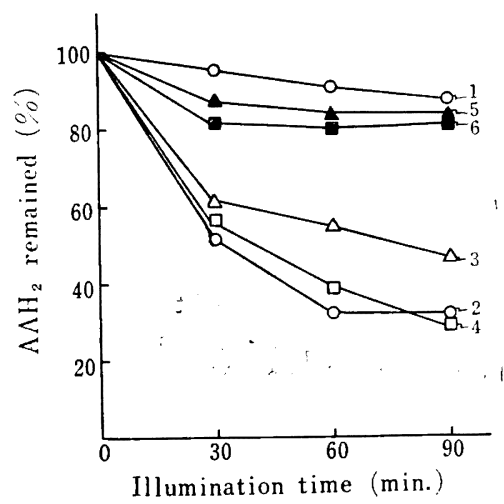

$\mathrm{AAH}_{2}: 10 \mathrm{mg} / 100 \mathrm{ml} \mathrm{MeOH}, \mathrm{pH} 5.0$ chl, a: $5 \mathrm{mg} / 100 \mathrm{ml} \mathrm{MeOH}$

1: $\mathrm{AAH}_{2} \mathrm{MeOH}$, under light

2: control $\left(\mathrm{AAH}_{2} \mathrm{MeOH}\right.$, chl. a $\mathrm{MeOH}$ without $\left.\mathrm{K}_{3} \mathrm{Fe}(\mathrm{CN})_{6}\right)$ under light

3: $10^{-5} \mathrm{M} \mathrm{K}_{3} \mathrm{Fe}(\mathrm{CN})_{6}$ added, under light

4: $10^{-4} \mathrm{M} \mathrm{K}_{3} \mathrm{Fe}(\mathrm{CN})_{6}$ added, under light

5: $10^{-5} \mathrm{M} \mathrm{K}_{3} \mathrm{Fe}(\mathrm{CN})_{6}$ added, in dark

6: $10^{-4} \mathrm{M} \mathrm{K}_{3} \mathrm{Fe}(\mathrm{CN})_{6}$ added, in dark

p-キノンの効果については第 3-2 図に示されるごとく $10^{-4} \mathrm{M}$ 淟度においてはクロロフィル- $\mathrm{AAH}_{2}$ 系の光分解 反応を促進する。これは Patterson ${ }^{12)} は p$ こノンによっ てAAH $\mathrm{AH}_{2}$ DHA に酸化され，自らはヒドロキノンに移 行することを報告しており，またフェノール化合物とく に゚ージフェノールが酸化酵素により反応性に富んだーキ ノンを生じ,このキノンが $\mathrm{AAH}_{2}$ を酸化し, 自らはのージ フェノールに還元されることは既に知られており ${ }^{13)}$ こ れらの点より $p$-キノンは 0 -キノンより反応性は劣るが 
oーキノンと同様にクロロフィルのケイ光を消光せしめる にかかわらず(第4-5図参照), $10^{-4} \mathrm{M}$ の高濃度において はそれ自体のケイ光と併せ $\mathrm{AAH}_{2}$ の接触酸化を增大する 性質がクロロフィル- $\mathrm{AAH}_{2}$ 系の光分解促進の原因をな するのと考兄られる10-5 濃度においてはクロロフィ ル $-\mathrm{AAH}_{2}$ 系の光酸化を抑制する。

Fig. 3-2. Effect of p-quinone upon the photochemical decomposition of chlorophyll-L-ascorbic acid system

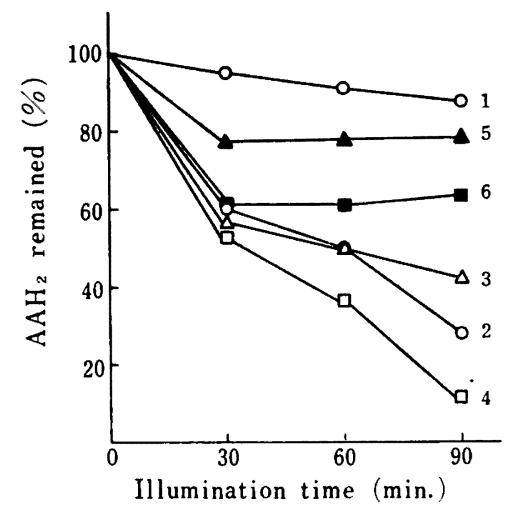

$\mathrm{AAH}_{2}: 10 \mathrm{mg} / 100 \mathrm{ml} \mathrm{MeOH}, \mathrm{pH} 5.0$ chl. a: $5 \mathrm{mg} / 100 \mathrm{ml} \mathrm{MeOH}$

1: $\mathrm{AAH}_{2} \mathrm{MeOH}$, under light

2: control( $\mathrm{AAH}_{2} \mathrm{MeOH}$, chl. a $\mathrm{MeOH}$ without $p$-quinone) under light

3: $10^{-5} \mathrm{M} p$-quinone added, under light

4: $10^{-4} \mathrm{M} p$-quinone added, under light

5: $10^{-5} \mathrm{M} p$-quinone added, in dark

6: $10^{-4} \mathrm{M} p$-quinone added, in dark

防カチンの効果については第 3-3図に示されるごと くクロロ>ィル- $\mathrm{AAH}_{2}$ 系の光分解反応の抑制がみられ, $10^{-5} \mathrm{M}$ に扎いてその抑制能が大きい。これは $\beta$-カロチン によるクロロフィルのケイ光強度にいちじるしい变化が みとめられず，また $\beta$-カロチン自体すケイ光を有する が (第4-6図参照)， $\beta$-カロチンの光エネルギー吸収にも とつく光增感作用よりす $\beta$-カロチン自体による $\mathrm{AAH}_{2}$ 酸 化抑制作用の大なることが原因と考兄られる。なお $\beta-$ カロチンの $\mathrm{AAH}_{2}$ 酸化抑制能についてはさらに検討を加 えたい。 $\beta$-カロチン (メルク製) は $10^{-5} \mathrm{M}$ 以上の濃度 ではメタノール溶液中でも溶解しがたく析出をみるため に本実験に打いては $10^{-6} \sim 10^{-5} \mathrm{M}$ の濃度域にて $\beta$-カ口 チンの効果をしらべた。

4. 反応系のケイ光スペクトル

クロロフィルは紫外光や可視光を吸収して励起され， 吸収された光ェネルギーの一部はケイ光またはリン光と して放出される。ケイ光は光化学反応で光化学反応にお いてどの位のエネルギーが与えられるかはケイ光強度を
Fig. 3-3. Effect of $\beta$-carotene upon the photochemical decomposition of chlorophyll-L-ascorbic acid system

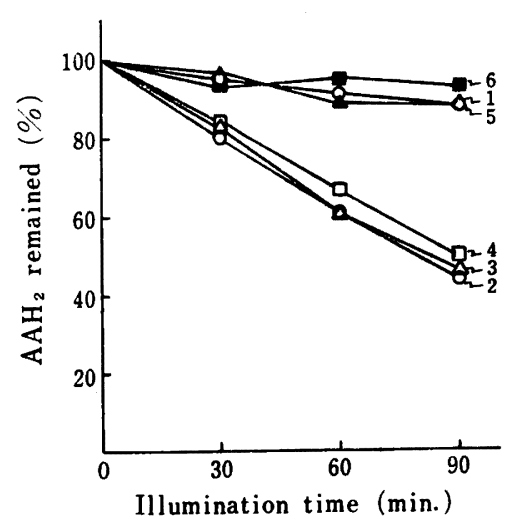

$\mathrm{AAH}_{2}: 10 \mathrm{mg} / 100 \mathrm{~m} l \mathrm{MeOH}, \mathrm{pH} 5.0$ chl. a: $5 \mathrm{mg} / 100 \mathrm{~m} l \mathrm{MeOH}$

1: $\mathrm{AAH}_{2} \mathrm{MeOH}$, under light

2: control $\left(\mathrm{AAH}_{2} \mathrm{MeOH}\right.$, chl. a $\mathrm{MeOH}$ without $\beta$-carotene) under light

3: $10^{-6} \mathrm{M} \beta$-carotene added, under light

4: $10^{-5} \mathrm{M} \beta$-carotene added, under light

5: $10^{-6} \mathrm{M} \beta$-carotene added, in dark

6: $10^{-5} \mathrm{M} \beta$-carotene added, in dark

測定すれば一応のめやすとなるので，クロロフィルによ る $\mathrm{AAH}_{2}$ の光增感反応追跡の手段として反応系のヶイ光 強度を測定し, 反応采のヶイ光強度と $\mathrm{AAH}_{2}$ の光分解度 との関係を検討した。

(1) クロロフィルa のケイ光スペクトル：クロロフィ ルa $\mathrm{MeOH}$ 溶液とクロロフィルa- $\mathrm{AAH}_{2}$ 系の両者につ いて, 島津製ヶイ光自記分光光度計 GSF-16型を用い, 励起波長 $550 \mathrm{~m} \mu$ にてケイ光スペクトルを求めた。結果 は第 4-1 図に示されるごとくケイ光波長 $685 \mathrm{~m} \mu$ (主ケ イ光帯) と $550 \mathrm{~m} \mu$ (副ケイ光带) に $\lambda \max$ がみとめら

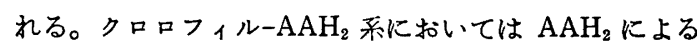
クロロフィルのケイ光強度の変化は全くみとめられな い。クロロフィルの濃度の相違によるケイ光強度は 5.0 $\mathrm{mg} \%$ クロフィル a $\mathrm{MeOH}$ 溶液を $2.5 \mathrm{mg} \%$ に希釈す ることにより主ケイ光 $(685 \mathrm{~m} \mu)$ の強度は約 $3 / 4$ に減少 する。

(2) フェオフィチンのケイ光スペクトル：フェオフィ チン $\mathrm{MeOH}$ 溶液およびフェオフィチン- $\mathrm{AAH}_{2} \mathrm{MeOH}$ 溶 液について励起波長 $550 \mathrm{~m} \mu$ にてそれぞれのケイ光スぺ クトルを求めた。結果は第 4-2 図に示されるごとくケイ 光波長 $685 \mathrm{~m} \mu$ と $565 \mathrm{~m} \mu$ さらに $645 \mathrm{~m} \mu$ に $\lambda \max$ か みとめられ, フェオフィチン- $\mathrm{AAH}_{2}$ 采についても $\mathrm{AAH}_{2}$ によるフェオフィチンのケイ光強度の变化はクロロフィ 
Fig. 4-1. Fluorescence spectra of chlorophyll and chlorophyll with L-ascorbic acid

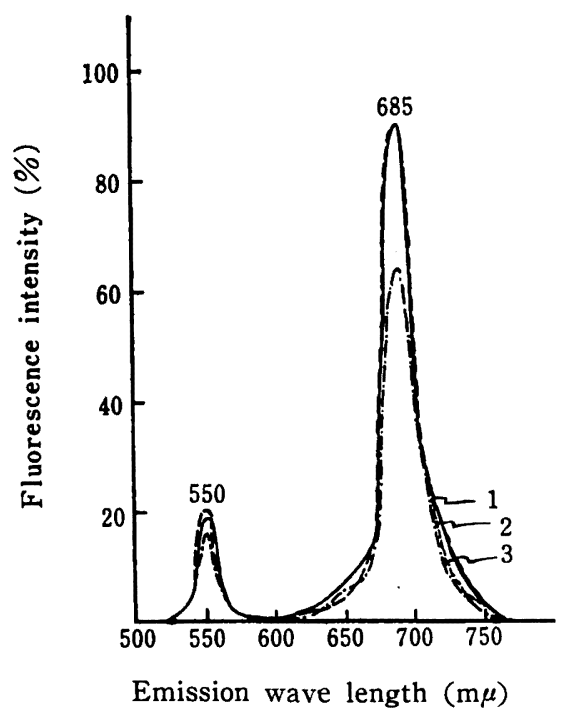

Excitation wave length: $550 \mathrm{~m} \mu$

1: chl. a $5 \mathrm{mg} / 100 \mathrm{ml} \mathrm{MeOH}$

2: chl. a $5 \mathrm{mg} / 100 \mathrm{~m} l \mathrm{MeOH}, \mathrm{AAH}_{2} 10 \mathrm{mg} / 100$ $\mathrm{m} l \mathrm{MeOH}$

3: chl. a $2.5 \mathrm{mg} / 100 \mathrm{~m} l \mathrm{MeOH}$

Fig. 4-2. Fluorescence spectra of pheophytin a and pheophytin with L-ascorbic acid

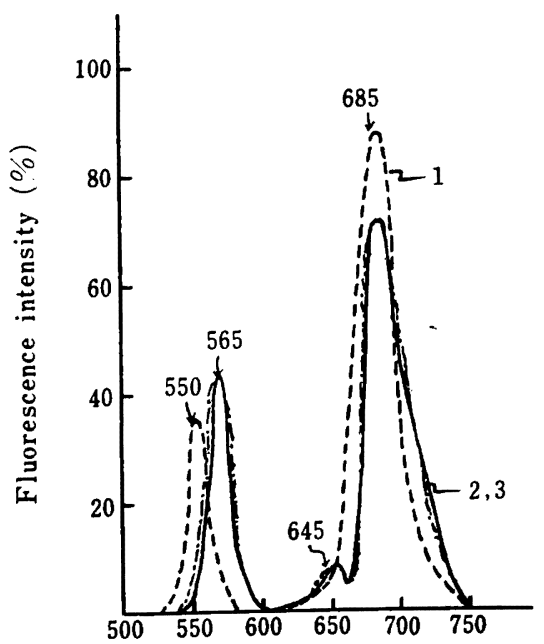

Emission wave length $(\mathrm{m} \mu)$

Excitation wave length: $550 \mathrm{~m} \mu$

1: chl. a $5 \mathrm{mg} / 100 \mathrm{~m} l \mathrm{MeOH}$

2: pheophytin a $5 \mathrm{mg} / 100 \mathrm{ml} \mathrm{MeOH}$

3: pheophytin a $5 \mathrm{mg} / 100 \mathrm{ml} \mathrm{MeOH}, \mathrm{AAH}_{2}$ $10 \mathrm{mg} / 100 \mathrm{~m} l \mathrm{MeOH}$
ルのときと同様全くみとめられない。なお $5 \mathrm{mg} \%$ 嶩度 についてクロロフィルとフェオフィチンのケイ光強度を 主ヶイ光帯 $685 \mathrm{~m} \mu$ について比較すると後者は前者の約 $4 / 5$ のケイ光強度を示す。

(3) 鉄クロロフィリンナトリウムおよび銅クロロフィ リンナトリウムのケイ光スペクトル：鉄クロロフィリン ナトリウム水溶液拈よび銅クロロフィリンナトリウム水 溶液について励起波長 $550 \mathrm{~m} \mu$ にてケイ光スペクトルを 求めた。結果は第 4-3 図に示されるごとく両者ともに ケイ光波長 $550 \mathrm{~m} \mu$ (主ヶイ光帯) に $\lambda \max$ がみとめら れ，とくにクロロフィル扰びフェオフィチンにみとめ られた $685 \mathrm{~m} \mu$ の $\lambda \max$ はほとんど消失することが注 目される。また $550 \mathrm{~m} \mu$ に扣けるケイ光強度は銅ク口ロ フィリンナトリウムはクロロフィル，鉄クロロフィリン ナトリウムに比較していちじるしく小さい。な打両者の 水溶液と $\mathrm{MeOH}$ 溶液について $550 \mathrm{~m} \mu$ におけるヶイ光 強度を比較したか，溶媒（水と $\mathrm{MeOH}$ ) に上るケイ光強 度の相違はみとめられない。

Fig. 4-3. Fluorescence spectra of Fe-chlorophyllin$\mathrm{Na}$ and $\mathrm{Cu} \cdot$ chlorophyllin- $\mathrm{Na}$

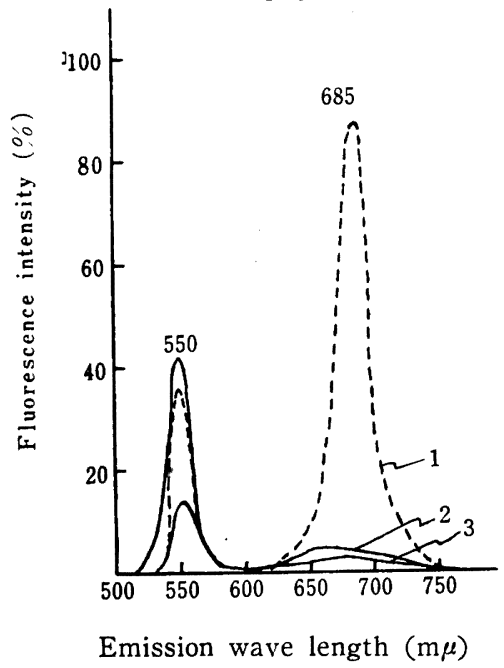

Excitation wave length: $550 \mathrm{~m} \mu$

1: chl. a $5 \mathrm{mg} / 100 \mathrm{~m} l \mathrm{MeOH}$

2: Fe-chlorophyllin $\mathrm{Na} 5 \mathrm{mg} / 100 \mathrm{~m} l$ as aqeous solution

3: Cu-chlorophyllin $\mathrm{Na} 5 \mathrm{mg} / 100 \mathrm{~m} l$ as aqeous solution

(4) フェリシアン化カリウム， $p$-キノンおよび $\beta$-カ ロチン共存下のクロロフィルのケイ光スペクトル：クロ ロフィル a $\mathrm{MeOH}$ 溶液に反応液中の濃度 $10^{-5} \sim 10^{-4} \mathrm{M}$ にフェリシアン化カリウム, $p$-キノン㧍よび $\beta$-カロチ ンをそれぞれ添加し，励起波長 $550 \mathrm{~m} \mu$ にてケイ光スペ クトルを求めた。結果は第4-4図，第4-5図，第4-6図に 
Fig. 4-4. Fluorescence spectra of chlorophyll a with potassium ferricyanide

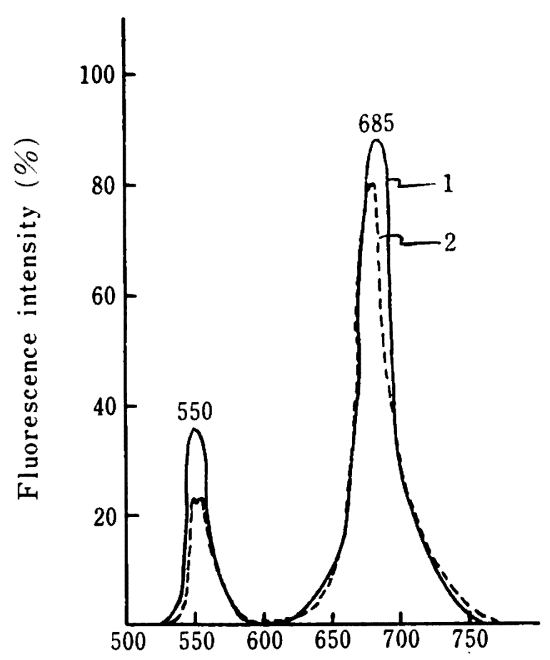

Emission wave length $(\mathrm{m} \mu)$

Excitation wave length: $550 \mathrm{~m} \mu$

1: chl. a $5 \mathrm{mg} / 100 \mathrm{~m} l \mathrm{MeOH}$

2: chl. a $5 \mathrm{mg} / 100 \mathrm{~m} l \mathrm{MeOH}, 10^{-4} \mathrm{M} \mathrm{K}_{3} \mathrm{Fe}$ $(\mathrm{CN})_{6}$

Fig. 4-5. Fluorescence spectra of chlorophyll a with $p$-quinone

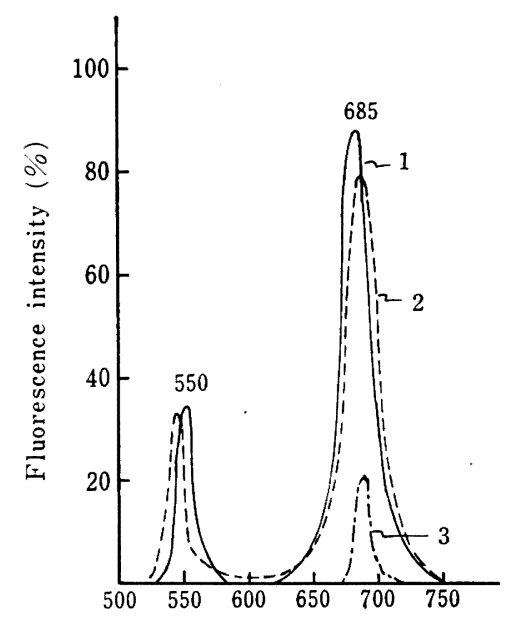

Emission wave length $(\mathrm{m} \mu)$

Excitation wave length: $550 \mathrm{~m} \mu$

1: chl. a $5 \mathrm{mg} / 100 \mathrm{ml} \mathrm{MeOH}$

2: chl. a $5 \mathrm{mg} / 100 \mathrm{ml} \mathrm{MeOH}, 10^{-4} \mathrm{M}$ p-quinon

3: $10^{-4} \mathrm{M}$ p-quinone $\mathrm{MeOH}$

示されるごとくクロロフィルa のケイ光波長 $685 \mathrm{~m} \mu$ お よび $550 \mathrm{~m} \mu$ に批於光強度はフェリシアン化カリ ウム扰よび $p$-キノンにより若千のケイ光消光がみとめ られるが， $\beta$-カロチン $\left(10^{-5} \mathrm{M}\right)$ によるケイ光消光は 685 $\mathrm{m} \mu$ においては全くみとめられない。なお $\beta$ 一カロチンの
Fig. 4-6. Fluorescence spectra of chlorophyll a with $\beta$-carotene

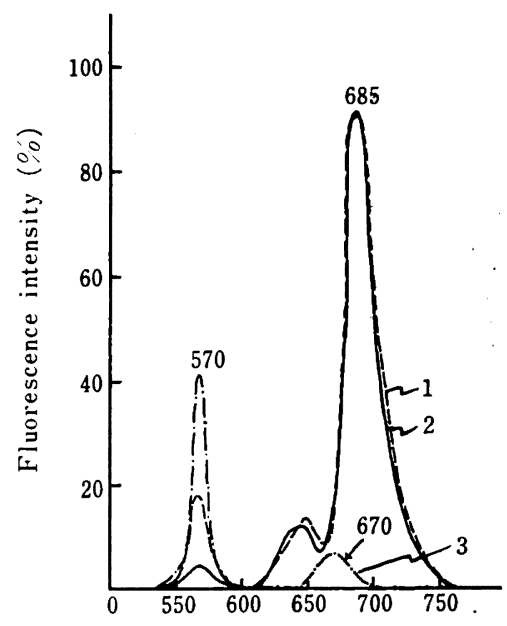

Emission wave length $(\mathrm{m} \mu)$

Excitation wave length: $550 \mathrm{~m} \mu$

1: "chl. a $5 \mathrm{mg} / 100 \mathrm{~m} l \mathrm{MeOH}$

2: chl. a $5 \mathrm{mg} / 100 \mathrm{~m} l \mathrm{MeOH}, 10^{-5} \mathrm{M} \beta$-carotene

3: $10^{-5} \mathrm{M} \beta$-carotene $\mathrm{MeOH}$

場合にはケイ光波長 $570 \mathrm{~m} \mu$ と $670 \mathrm{~m} \mu$ に $\beta$-カロチン自体 によるケイ光帯がみとめられ, $p$-キノンの場合は $685 \mathrm{~m} \mu$ に $p$-キノン自体のわずかなケイ光帯がみとめられる。

5. 反応系のケイ光強度と $\mathrm{L}$ ーアスコルビン酸光分解 との関係

ケイ光は光化学反応でクロロフィルおよびクロロフィ ル誘導体による $\mathrm{AAH}_{2}$ の光增感分解反応は, 反応系のそ れぞれのケイ光強度の測定により一応のめやすがえられ るものと考兄, 上記の第4-1〜第4-6図の吸収スペクトル に示されるそれぞれの主ケイ光帯 $685 \mathrm{~m} \mu$ に批けるケイ 光強度と第 1 図 第 3 困に示されるそれぞれの照射処理 1 時間後の $\mathrm{AAH}_{2}$ 光分解度との関係を求めた。な打励起 波長 $550 \mathrm{~m} \mu$ ，ヶイ光波長(主ケイ光帯) $685 \mathrm{~m} \mu$ に打け るクロロフィルのケイ光強度を 100 とし, それぞれの反 応系のケイ光強度はクロロフィルのケイ光強度との相対 比較値をもって示した。反応系の $\mathrm{AAH}_{2}$ の光分解度も》 ロロフィル- $\mathrm{AAH}_{2}$ 系の $\mathrm{AAH}_{2}$ の光分解度を 100 とし, それぞれの反応系の $\mathrm{AAH}_{2}$ の光分解率はクロロフィルー $\mathrm{AAH}_{2}$ 系との相対比較值をすうて示した。な敃第 5 図に 示される $\mathrm{AAH}_{2}$ の光分解率は, 暗所処理(反応時間 1 時 間)に岕ける $\mathrm{AAH}_{2}$ の自動酸化, 鉄クロロフィリンナト リウム, 銅クロロフィリンナトリウム, フェリシフン化 カリウム, $p$-キノン自体による $\mathrm{AAH}_{2}$ の酸化分解值を 差引いたそれぞれの $\mathrm{AAH}_{2}$ 光增感分解率を示す。結果 は第 5 図に示されるごとく, $550 \mathrm{~m} \mu$ の副ケイ光帯, さ らに $\beta$-カロチン自体にもとつくくケイ光を考虑していな 
いため反応系におけるケイ光強度と $\mathrm{AAH}_{2}$ 光分解率と の間には十分な相関関係を見出しえないが，クロロフィ ルの主ケイ光帯 $685 \mathrm{~m} \mu$ に拈けるケイ光強度をるとにし て考えるとフェオフィチンのケイ光強度はクロロフィル のそれに比較して小さく，フェオフィチンー $\mathrm{AAH}_{2}$ 系に おける $\mathrm{AAH}_{2}$ の光分解率すクロロフィルー- $\mathrm{AAH}_{2}$ 系に比 較して小さい。鉄クロロフィリンナトリウム, 銅クロロ フィリンナトリウムは $550 \mathrm{~m} \mu$ にケイ光帯をるつが 685 $\mathrm{m} \mu$ におけるケイ光はいちじるしく小さくこれらの反 疬系に拈ける $\mathrm{AAH}_{2}$ の光分解率はもっと低い。ク口 ロフィル- $\mathrm{AAH}_{2}$ 系にフェリシアン化カリウム, $p$ リー ンおよび $\beta$-カロチンを添加すると，ヶイ光強度の消光 と $\mathrm{AAH}_{2}$ の光分解率の低下がみとめられる。なお $p$-キ ノン自体によるクロロフィルの酸化分解は，本実験条件 下（10-4 M, 反応 1 時間）においてはほとんどみとめら れない。

Fig. 5. Relationship between the fluorescence intensity of reaction system and the photochemical decomposition of L-ascorbic acid
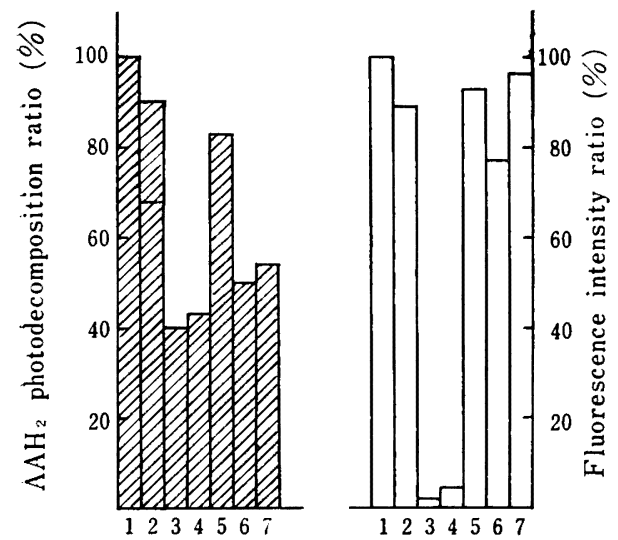

$\mathrm{AAH}_{2}: 10 \mathrm{mg} / 100 \mathrm{~m} l \mathrm{MeOH}$

1: chl. a $5 \mathrm{mg} / 100 \mathrm{ml} \mathrm{MeOH}$ added

2: pheophytin a $5 \mathrm{mg} / 100 \mathrm{ml} \mathrm{MeOH}$ added

3: Fe-chlorophyllin- $\mathrm{Na} 5 \mathrm{mg} / 100 \mathrm{ml}$ as aqeous soln added

4: $\mathrm{Cu}$-chlorophyllin- $\mathrm{Na} 5 \mathrm{mg} / 100 \mathrm{ml}$ as aqeous soln added

5: chl. a $5 \mathrm{mg} / 100 \mathrm{ml} \mathrm{MeOH}, 10^{-4} \mathrm{M} \mathrm{K} \mathrm{K}_{3} \mathrm{Fe}$ $(\mathrm{CN})_{B}$ added

6: chl. a $5 \mathrm{mg} / 100 \mathrm{ml} \mathrm{MeOH}, 10^{-4} \mathrm{M}$ p.quinone added

7: chl. a $5 \mathrm{mg} / 100 \mathrm{~m} l \mathrm{MeOH}, 10^{-5} \mathrm{M} \beta$-carotene added
要約

クロロフィル a，フェオフィチンおよびクロロフィル 金属誘導体による Lーアスコルビン酸の光増感分解さら にヶイ光消光刘としてのフェリシアン化カリウム, $p-キ$ ノンおよび $\beta$-カロチン共存下におけるクロロフィルーア スコルビン酸系の光分解反応をしらべ次の結果を得た。

1.クロロフィルa扰よ゙フェオフィチンは Lーアス コルビン酸の光分解をいちじるしく促僬する。

2. 銅クロロフィリンナトリウムおよび鉄クロロフィ リンナトリウムはレーアスコルビン酸の光分解を促進し， とくに前者による Lーアスコルビン 酸の光分解がいちじ るしい。また銅クロロフィリンナトリウムは Lーアスコ ルビン酸をいちじるしく接触酸化する。

3. クロロフィルーアスコルビン酸系の光分解反応に 対し，フェリシアン化カリウム， $p$ キキノン，扰よび $\beta$ カロチンは抑制作用を示す。

4. クロロフィルa, フェオフィチンのメタノール溶 液は比較的強いケイ光強度を示し，銅クロロフィリンナ トリウム扎よひ鉄クロロフィリンナトリウム水溶液のケ イ光強度は比較的小さい。さらにクロロフィルaのケイ 光強度はフェリシアン化カリウム，およびp-キノンによ り消光を5ける。

5. 反応系のケイ光強度と $\mathrm{L}$ ーアスコルビン酸光分解 との間には相関関係をもつ。

\section{文献}

1）守 康則，西山幹子, 諸富節子: 栄養と食糧, 22, 12 (1969)

2) Fujimori, E. \& Livigston, R.: Nature, 180 1036 (1957)

3) Claes, H.: Z. Naturforsch., 166, 445 (1961)

4) 守 康則, 池田由美子, 松本苗美, 繩田尚子：采 養と食糧，22，115（1969）

5) Pennington, F. C., Strain, H. H., Sree, W. A. \& Katz, J. J.: J. Am. Chem. Soc., 86, 1418 (1964)

6) A. O.A.C.: Official Method of Analysis, 9th ed (1960)

7) Roe, J. H. \& Oesterling, M. J.: J. Biol. Chem., 152, 511 (1954)

8) Dutton, H. J., Manning, W. M. \& Duggan, B. M.: J. Phys.Chem., 47, 308 (1943)

9) Wassink, E. C. \& Kersten, J. A. H.: Enzymologia., 10, 285 (1946)

10）村田紀夫：蛋白質・核酸・酵素，13，62(1968)

11) Murata, N. \&Takamiya, A.: Plant \& Cell. Physiol., 8, 683 (1967)

12) Patterson, J. W.: J. Biol. Chem., 183,81(1950)

13) Ingraham, L. L.: J. Am. Chem. Soc., 78, 5095 (1956) 